\title{
PENGGUNAAN MATERIAL LOKAL QUARRY MUARA TAKUS SEBAGAI BAHAN CAMPURAN LAPISAN PONDASI ATAS PADA PEKERASAN JALAN RAYA
}

\author{
Fitridawati Soehardi \\ Program Studi Teknik Sipil Universitas Lancang Kuning \\ Jalan Yos Sudarso Km. 8 Rumbai Pekanbaru \\ E-mail : fitridawati@unilak.ac.id
}

\begin{abstract}
Abstrak
Kabupaten Kampar merupakan salah satu daerah di Provinsi Riau yang mempunyai banyak sumber material yang dapat digunakan sebagai bahan lapis pondasi pada jalan raya. Hampir setiap tahunnya material-material ini dieksploitasi secara besar-besaran untuk memenuhi kebutuhan infrastruktur terutama pekerjaan jalan raya. Sehingga dengan bertambahnya kebutuhan terhadap material-material tersebut dapat mengakibatkan deposit material di daerah tersebut akan semakin berkurang. Jika tidak ada upaya penanganan guna mencari sumber-sumber material alternatif lainnya, kemungkinan besar daerah ini harus mendatangkan material-material tersebut dari daerah lain yang tentunya membutuhkan biaya trasportasi yang relatif tinggi. Penelitian ini menggunakan Agregat Desa Muara Takus sebagai agregat halus dan Kasar. Metode yang digunakan dalam penelitian adalah metode eksperimen. Pengujian meliputi uji kadar air, gradasi, abrasi, pemadatan, dan California Bearing Ratio (CBR). Hasil penelitian menunjukkan bawa agregat Desa Muara Takus memenuhi Spesifiksi Umum 2010 Revisi 3 dengan abrasi $=33,7 \%$, butiran pecah $=100 / 98,82$, Nilai CBR $=62,28 \%$, sementara $\gamma \mathrm{d} \max =2,187 \mathrm{gr} / \mathrm{cm}^{3}$ and wopt $=5,37 \%$.
\end{abstract}

Kata Kunci : Lapisan Pondasi Atas, Material Muara Takus

\begin{abstract}
Kampar Regency is one of the areas in Riau Province that has many sources of material that can be used as a material layer of foundation on the highway. Almost every year these materials are heavily exploited to meet infrastructure needs, especially road works. So with the increasing need for these materials can result in material deposits in the area will be reduced. If there are no handling efforts to find alternative sources of alternative materials, it is likely that these areas will have to bring these materials from other areas that would require relatively high transportation costs. This research uses Aggregate of Muara Takus Village as fine and coarse aggregate. The method used in this research the experimental method. The tests include water content test, gradation, Atterberg boundaries, abrasion, compaction, and California Bearing Ratio (CBR). The results showed that aggregate of Muara Takus Village fulfilled General Specification 2010 Revision 3 with abrasion $=33,7 \%$, breaking granule $=100 / 98,82$, CBR value $=$ $62,28 \%$, while $\gamma d \max =2,187 \mathrm{gr} / \mathrm{cm}^{3}$ and wopt $=5,37 \%$.
\end{abstract}

Keywords : Top Base Layer, Muara Takus Material 


\section{A. PENDAHULUAN}

Kabupaten Kampar merupakan salah satu daerah di Provinsi Riau yang memiliki banyak sumber material yang dapat dipergunakan sebagai bahan lapisan pondasi jalan raya. Hal ini disebebkan oleh pengaruh letak geografis Kabupaten Kampar yang berbatasan dengan Provinsi Sumatera Barat.

Material-material ini setiap tahunnya diekplorasi secara besarbesaran baik oleh perusahaan maupun oleh masyarakat sekitar. Material tersebut dipergunakan untuk memenuhi kebutuhan yang cukup besar dalam membangun infrastruktur khususnya jalan raya.

Kebutuhan yang begitu besar akan mengakibatkan terjadinya pasokan material di daerah tersebut akan semakin berkurang. Jika hal ini tidak ada upaya pencegahannya dapat di khawatirkan dimasa yang akan datang daerah ini harus mendatangkan material-material tersebut dari daerah lain namun pasti membutuhkan biaya mobilisasi yang cukup besar.

Salah satu upaya untuk mencegah terjadi hal tersebut adalah dengan mencari alternatif quarry-quarry lain yang mempunyai kualitas yang baik serta mudah dalam akses memperolehnya.

Berdasarkan permasalahan di atas penulis merasa tertarik melakukan penelitian mengenai penggunaan agregat dari daerah Koto Kampar yang berasal dari Desa Muara Takus.

\section{B. TINJAUAN PUSTAKA}

Sentosa dkk, (2010), agregat sungai adalah agregat yang diambil dari dasar sungai, umumnya berupa agregat dari jenis batuan sedimen. Akibat arus air sungai, agregat sungai umumnya berbentuk bulat dan tekstur permukaan cenderung licin. Pemanfaatan agregat Sungai Kampar di bidang konstruksi adalah sebagai agregat penyusun beton semen dan sebagai batu hias. Dalam pemanfaatannya terkadang batu sungai di pecah untuk mendapatkan bentuk dan bidang pecah yang sesuai serta tekstur permukaan yang kasar.

\section{Lapisan Pondasi Atas}

Lapisan pondasi atas merupakan lapisan perkerasan yang terletak diantara lapisan pondasi bawah dan lapisan permukaan. Akibat letak lapisan ini tepat berada di bawah permukaan perkerasan, maka lapisan ini menerima pembebanan yang berat dan paling ekstrim akibat muatan kendaraan. Sehingga material yang digunakan harus berkualitas sangat tinggi dan pelaksanaan kontruksi harus dilakukkan dengan teliti dan cermat. Lapisan pondasi atas atau base course mempunyai fungsi sebagai berikut : lapisan perkerasan ini menahan gaya lintang dari beban roda dan menyebarkan kearah lapisan di bawahnya. Lapisan ini merupakan peresapan untuk lapisan pondasi bawah. Sebagai bantalan terhadap lapisan permukaan diatasnya.

Menurut Hardiyatmo (2011), persyaratan lapis pondasi atas (base course) lebih ketat dibandingkan dengan persyaratan lapis pondasi bawah (subbase course) atau tanah dasar (subgrade). Bahan-bahan lapis pondasi atas harus cukup kuat dan awet, sehingga dapat menahan beban-beban yang bekerja padanya. Oleh karena itu sebelum menentukan bahan-bahan untuk lapis pondasi atas, maka perlu dilakukan pengujian bahan. Untuk beban lalu-lintas tinggi, agregat juga sering distabilisasi dengan bahan-bahan tertentu.

Nilai CBR merupakan kriteria utama dalam menentukan kekuatan 
lapisan pondasi. Sehingga dalam pemilihan gradasi ametrial harus memperhatikan keawetan atau ketahanan material itu sendiri. Hal ini diperlukan untuk mempertahankan kualitas lapisan perkerasan jalan.

\section{Persyaratan Agregat}

Agregat merupakan kombinasi dari batu pecah, kerikil dan pasir atau kombinasi material lain yang dapat digunakan dalam campuran beton aspal. Proporsi agregat kasar, agregat halus dan bahan pengisi (filler) didasarkan kepada spesifikasi dan gradasi yang telah ditentukan. Jumlah agregat di dalam campuran aspal biasanya 90 sampai 95 persen dari berat, atau 75 sampai 85 persen dari volume. Agregat dapat diperoleh secara alami atau buatan.

Fraksi agregat kasar yang tertahan pada ayakan $4,75 \mathrm{~mm}$ harus terdiri atas partikel yang keras dan awet. Bahan yang pecah bila berulang-ulang dibasahi dan dikeringkan tidak boleh digunakan (Achmad, 2017).

Sedangkan untuk fraksi agregat halus yang lolos ayakan 4,75 $\mathrm{mm}$ harus terdiri atas partikel pasir alami atau batu pecah halus dan partikel halus lainnya. Agregat untuk lapis pondasi harus bebas dari bahan organik dan gumpalan lempung atau bahan-bahan lain yang tidak dikehendaki, harus memenuhi ketentuan gradasi yang diberikan dalam Tabel 1 dan memenuhi sifat-sifat yang diberikan dalam Tabel 3 (Spesifikasi Umum, 2010, Revisi 3).

Spesifikasi pengujian agregat kasar sesuai dengan Spesifikasi Binamarga 2010 Revisi 3 dapat dilihat pada Tabel 1 dan spesifikasi pengujian agregat halus sesuai dengan Spesifikasi Binamarga 2010 Revisi 3 dapat dilihat pada Tabel 2.

Tabel 1. Ketentuan Agregat Kasar

\begin{tabular}{|c|c|c|c|c|}
\hline \multicolumn{3}{|c|}{ Pengujian } & Standar & Nilai \\
\hline \multirow{2}{*}{\multicolumn{2}{|c|}{$\begin{array}{llll}\text { Kekekalan } & \text { Bentuk } & \text { Agregat } & \text { Terhadap } \\
\text { Larutan } & & & \\
\end{array}$}} & Natrium Sulfat & \multirow[t]{2}{*}{ SNI 3407:2008 } & Maks $12 \%$ \\
\hline & & Magnesium Sulfat & & Maks $18 \%$ \\
\hline \multirow{4}{*}{$\begin{array}{l}\text { Abrasi dengan } \\
\text { mesin Los } \\
\text { Angeles }\end{array}$} & \multirow[t]{2}{*}{ Campuran AC Modifikasi } & 100 Putaran & \multirow[t]{4}{*}{ SNI 2417:2008 } & Maks 6\% \\
\hline & & 500 Putaran & & Maks 30\% \\
\hline & \multirow{2}{*}{$\begin{array}{l}\text { Semua Jenis Campuran } \\
\text { Aspal bergradasi lainnya }\end{array}$} & 100 Putran & & Maks $8 \%$ \\
\hline & & 500 Putaran & & Maks $40 \%$ \\
\hline \multicolumn{3}{|c|}{ Kelekatan Agregat Terhadap Aspal } & SNI 2439:2011 & Maks 95\% \\
\hline \multicolumn{3}{|c|}{ Butir Pecah Pada Agregat Kasar } & SNI 7619:2012 & $95 / 90$ \\
\hline \multicolumn{3}{|c|}{ Partikel Pipih dan Lonjong } & $\begin{array}{c}\text { ASTM D4791 } \\
\text { Perbandingan 1:5 }\end{array}$ & Maks $10 \%$ \\
\hline \multicolumn{3}{|c|}{ Material Lolos Ayakan No.200 } & SNI 03-4142-1996 & Mak \\
\hline
\end{tabular}

(Sumber : Spesifikasi Umum Bina Marga, 2010 Revisi 3)

Tabel 2. Ketentuan Agregat Halus

\begin{tabular}{lcc}
\multicolumn{1}{c}{ Pengujian } & Standar & Nilai \\
\hline Nilai Setara Pasir & SNI 03-4428-1997 & Min 60\% \\
\hline Angularitas dengan Uji Kadar Rongga & SNI 03-6877-2002 & Min 45 \\
\hline $\begin{array}{l}\text { Gumpalan Lempung dan Butir-butir Mudah } \\
\text { Pecah dalam Agregat }\end{array}$ & SNI 03-4141-1996 & Maks 1\% \\
\hline Agregat Lolos Ayakan No.200 & SNI ASTM C117:2012 & Maks 10\% \\
\hline
\end{tabular}

(Sumber : Spesifikasi Umum Bina Marga, 2010 Revisi 3) 
Spesifikasi Sifat Lapisan Pondasi Agregat sesuai dengan Spesifikasi Binamarga 2010 Revisi 3 dapat dilihat pada tabel 3 .

\section{Gradasi Agregat}

Gradasi adalah susunan butir agregat sesuai ukurannya, ukuran agregat dapat diperoleh melalui pemeriksaan analisis saringan. Satu set saringan umumnya terdiri dari saringan berukuran 3/4", 1/2", 3/8", No.4, No.8, No.16, No.30, No.50, No.100, No.200. Gradasi agregat dinyatakan dalam persentase lolos atau persentase tertahan yang dihitung berdasarkan berat agregat. Gradasi agregat menentukan besarnya rongga atau pori yang mungkin terjadi dalam agregat campuran, campuran agregat yang baik adalah agregat yang terdiri dari agregat berukuran besar sampai kecil secara merata, hal tersebut dikarenakan rongga yang terbentuk oleh agregat berukuran besar akan diisi oleh agregat yang lebih kecil.

Agregat bergradasi baik adalah agregat yang ukuran butirnya terdistribusi merata dalam satu rentang ukuran butir. Agregat bergradasi baik disebut pula agregat bergradasi rapat. Campuran agregat bergradasi baik mempunyai pori sedikit, mudah dipadatkan dan mempunyai stabilitas yang tinggi. Dalam memilih gradasi agregat campuran, kecuali untuk gradasi Latasir dan Lataston, maka campuran jenis Laston perlu memperhatikan Kurva Fuller, Titik Kontrol dan Zona Terbatas Gradasi. Pada Spesifikasi Umum Bina Marga Tahun 2010 Revisi 3, beton aspal campuran panas menetapkan gradasi dengan 2 (dua) spesifikasi khusus yaitu target gradasi berada di titik kontrol dan menghindari daerah larangan. Seperti terlihat pada tabel 4.

Tabel 3. Sifat-sifat Lapis Pondasi Agregat

\begin{tabular}{|c|c|c|c|}
\hline Sifat-Sifat & Kelas A & Kelas B & Kelas C \\
\hline Abrasi dari Agregat Kasar (SNI 2417:2008) & $0-40 \%$ & $0-40 \%$ & $0-40 \%$ \\
\hline Butiran Pecah, Tertahan ayakan 3/8"(SNI 7619:2012) & $95 / 90^{1)}$ & $55 / 50^{2)}$ & $55 / 50^{2)}$ \\
\hline Batas Cair (SNI 1967:2008) & $0-25$ & $0-35$ & $0-35$ \\
\hline Indeks Plastisitas (SNI 1966:2008) & $0-6$ & $0-10$ & $4-15$ \\
\hline Hasil Kali Indeks Plastisitas dengan \% Lolos Ayakan No.200 & Maks.25 & - & - \\
\hline $\begin{array}{l}\text { Gumpalan Lempung dan Butiran-butiran Mudah pecah } \\
\text { (SNI 1744:2012) }\end{array}$ & $0-5 \%$ & $0-5 \%$ & $0-5 \%$ \\
\hline CBR Rendam (SNI 1744:2012) & Min.90\% & Min.60\% & Min. $50 \%$ \\
\hline Perbandingan \% Lolos Ayakan No.200 dan No.40 & Maks.2/3 & Maks.2/3 & - \\
\hline \multicolumn{4}{|c|}{$\begin{array}{l}\text { Catatan: } \\
\text { 95/90 menunjukkan bahwa } 95 \% \text { agregat kasar mempunyai buka bidang pecah satu atau lebih dan } 90 \% \\
\text { agregat kasar mempunyai muka bidang pecah dua atau lebih } \\
55 / 50 \text { menunjukkan bahwa } 55 \% \text { agregat kasar mempunyai buka bidang pecah satu atau lebih dan } 50 \% \\
\text { agregat kasar mempunyai muka bidang pecah dua atau lebih }\end{array}$} \\
\hline
\end{tabular}

(Sumber : Spesifikasi Umum Bina Marga, 2010 Revisi 3) 
Tabel 4. Gradasi Lapisan Agregat

\begin{tabular}{ccccc}
\hline \multicolumn{2}{c}{ Ukuran Saringan } & \multicolumn{3}{c}{ Persen Berat Yang Lolos } \\
\hline ASTM & $(\mathbf{m m})$ & Kelas A & Kelas B & Kelas C \\
\hline $2 "$ & 50 & & 100 & \\
11 "” & 37,5 & 100 & $88-95$ & 100 \\
$1 "$ & 25,0 & $79-85$ & $70-85$ & $77-89$ \\
$3 / 8 "$ & 9,50 & $44-58$ & $30-65$ & $41-66$ \\
No.4 & 4,75 & $29-44$ & $25-55$ & $26-54$ \\
No.10 & 2,00 & $17-30$ & $15-40$ & $15-42$ \\
No.40 & 0,425 & $7-17$ & $8-20$ & $7-26$ \\
No.200 & 0,075 & $2-8$ & $2-8$ & $4-16$ \\
\hline
\end{tabular}

\section{Daya Tahan}

Daya tahan agregat merupakan ketahanan agregat terhadap adanya penurunan mutu akibat proses mekanis dan kimiawi. Agregat dapat mengalami degradasi, yaitu perubahan gradasi akibat pecahnya butir-butir agregat. Kehancuran agregat dapat disebabkan oleh proses mekanis, seperti gaya-gaya yang terjadi selama proses pelaksanaan perkerasan jalan penimbunan, penghamparan, pemadatan, pelayanan terhadap lalu lintas dan proses kimiawi seperti pengaruh kelembaban, kepanasan dan perubahan suhu sepanjang hari. Daya tahan agregat terhadap beban mekanis diperiksa dengan melakukan uji abrasi dengan alat Los Angeles Machine (Sukirman, 2005).

\section{DATA DAN ANALISA DATA \\ 1. Data}

Data sekunder adalah data yang diperoleh dari studi literatur dengan mempelajari penelitian-penelitian sejenis yang pernah dilakukan, teoriteori yang berkaitan denganmaterial agregat lapisan pondasi dan teknik analisis data yang dapat menunjang penelitian kemudian observasi lapangan dengan melakukan kunjungan langsung kelapangan dilakukan untuk melihat kondisi dan pengambilan sampel yang akan di dilakukan pengujian terhadap nilai abrasi, gradasi dan Nilai California Bearing Ratio (CBR) Laboratoriumnya.

Data primer adalah data yang diperoleh langsung di lapangan dan pengujian di laboratorium terhadap kualitas agregat yang diambil dari Desa Muara Takus Kecamatan Koto Kampar Kabupaten Kampar.

\section{Analisa Data}

Data-data hasil pengujian sampel agregat yang didapat sesuai dengan kondisi real di lapangan diteliti di laboratorium, dengan melakukan pengujian nilai abrasi, analisa saringan, berat jenis, nilai kadar air optimum, dan Nilai California Bearing Ratio (CBR). Berdasarkan hasil tersebut dapat diketahui sifat-sifat Lapisan Pondasi Agregat Kelas B, Gradasi dan Nilai California Bearing Ratio (CBR) Laboratoriumnya.

\section{HASIL DAN PEMBAHASAN \\ 1. Sifat-sifat Lapisan Pondasi Agregat Kelas B}

Berdasarkan pengujian sampel di laboratorium, maka diperoleh data hasil pengujian terhadap sifat- sifat lapisan pondasi agregat kelas B sesuai dengan persyaratan Spesifikasi Binamarga 2010 Revisi 3. HasilPengujian dapat dilihat pada Tabel 5. 


\section{Gradasi Agregat}

Berdasarkan pengujian analisa saringan pada sampeldapat diperoleh gradasi gabungan lapisan pondasi agregat kelas B sesuai dengan persyaratan spesifikasi Binamarga 2010 Revisi 3. Hasil pengujian yang dapat dilihat pada tabel 6 .

Untuk grafik gradasi lapisan pondasi agregat kelas B sesuai dengan persyaratan spesifikasi Binamarga 2010 Revisi 3 dapat dilihat pada Gambar 7.

Gambar 7 menunjukan bahwa hasil pengujian analisa saringan diperoleh gradasi dan proporsi aggregat quarry desa muara takus memenuhi persyaratan batas atas dan batas bawah lapisanpondasi atas kelas B pada spesifikasi Binamarga 2010 Revisi 3.

Tabel 5. Hasil Pengujian Sifat-sifat Lapis Pondasi Agregat Kelas B

\begin{tabular}{clccc}
\hline No & \multicolumn{1}{c}{ Jenis Pengujian } & Satuan & Hasil & $\begin{array}{c}\text { Batas Spesifikasi } \\
\text { Binamarga 2010 Revisi 3 }\end{array}$ \\
\hline 1 & Abrasi Agregat Kasar & $\%$ & 33,7 & $0-40$ \\
\hline 2 & Butiran Pecah, Tertahan 3/8" & $\%$ & $100 / 98,82$ & $55 / 50$ \\
\hline 3 & Pemadatan Modified & & & \\
& Kadar Air Optimum (Wopt) & $\%$ & 5,37 & - \\
& dmaks & $\mathrm{Gr} / \mathrm{Cm}^{3}$ & 2,187 & - \\
& $95 \%$ dmaks & $\mathrm{Gr} / \mathrm{Cm}^{3}$ & 2,077 & Min 60\% \\
\hline 4 & CBR & $\%$ & 62,28 & Maks 2/3 \\
\hline 5 & Perbandingan \% Lolos Ayakan & $\%$ & 0,38 & \\
& No.200 dan No.40 & & & \\
\hline
\end{tabular}

Tabel 6. Hasil Pengujian Gradasi Gabungan

\begin{tabular}{|c|c|c|c|c|c|c|c|c|c|}
\hline \multirow{2}{*}{\multicolumn{2}{|c|}{$\begin{array}{c}\text { Nomor } \\
\text { Saringan }\end{array}$}} & \multirow{2}{*}{\multicolumn{5}{|c|}{$\begin{array}{c}\text { Gradasi Masing- masing Fraksi } \\
\text { (Persentasi Lolos Saringan) }\end{array}$}} & \multirow{4}{*}{$\begin{array}{c}\text { Rata - } \\
\text { rata } \\
100 \%\end{array}$} & \multirow{2}{*}{\multicolumn{2}{|c|}{$\begin{array}{l}\text { Spesifikasi Lolos } \\
\text { Saringan }\end{array}$}} \\
\hline & & & & & & & & & \\
\hline \multirow{2}{*}{ ASTM } & \multirow{2}{*}{$\mathbf{m m}$} & \multicolumn{5}{|c|}{ Sampel } & & Batas & Batas \\
\hline & & 1 & 2 & 4 & 5 & 6 & & Bawah & Atas \\
\hline $2 "$ & 50,000 & 100,00 & 100,00 & 100,00 & 100,00 & 100,00 & 100,00 & 100 & 100 \\
\hline $11 / 2^{\prime \prime}$ & 38,100 & 48,30 & 100,00 & 100,00 & 100,00 & 100,00 & 89,66 & 88 & 95 \\
\hline $1^{\prime \prime}$ & 25,400 & 37,38 & 72,09 & 100,00 & 100,00 & 100,00 & 72,13 & 70 & 85 \\
\hline $3 / 8^{\prime \prime}$ & 9,520 & 2,61 & 32,00 & 43,20 & 100,00 & 100,00 & 35,74 & 30 & 65 \\
\hline No. 4 & 4,760 & 2,49 & 22,00 & 26,50 & 98,52 & 100,00 & 28,04 & 25 & 55 \\
\hline No. 10 & 2,000 & 2,44 & 3,17 & 12,61 & 64,70 & 99,84 & 15,85 & 15 & 40 \\
\hline No. 40 & 0,425 & 2,15 & 2,37 & 9,97 & 33,89 & 60,86 & 10,33 & 8 & 20 \\
\hline No. 200 & 0,075 & 1,30 & 0,62 & 1,21 & 13,05 & 26,91 & 3,98 & 2 & 8 \\
\hline
\end{tabular}




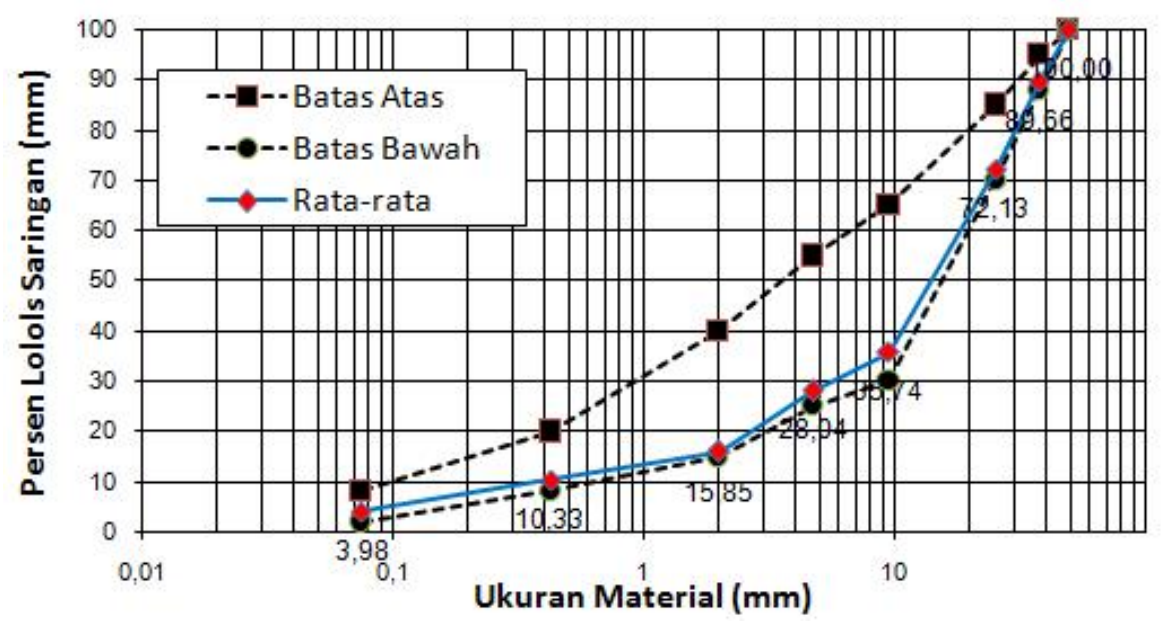

Gambar 7. Gradasi Agregat

\section{Pengujian California Bearing Ratio (CBR)}

Pengujian terhadap nilai California Bearing Ratio (CBR), pengujian dilakukan dengan mengunakan 3 variasi jumlah tumbukan yaitu 10,35 dan 65 tumbukan. Hasil pengujian California Bearing Ratio (CBR) dapat dilihat pada Gambar 8.

Dari Gambar 8 dapat dilihat, bahwa hasil pengujian California Bearing Ratio (CBR) diperoleh nilai California Bearing Ratio (CBR) sebesar $62,28 \%$ dan masih memenuhi spesifikasi Binamarga 2010 Revisi 3.

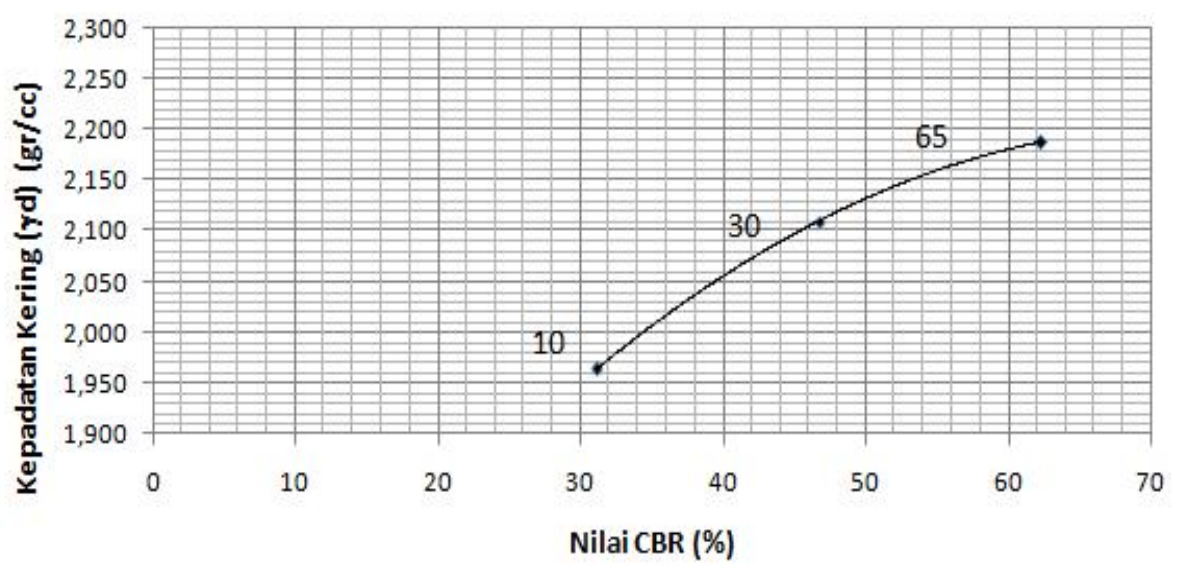

Gambar 8. Nilai California Bearing Ratio (CBR)

\section{E. KESIMPULAN}

Dari hasil pengujian dilaboratorium maka diperoleh kesimpulan sebagai berikut:

1. Hasil pengujian di laboratorium menunjukkan bahwa nilai Abrasi adalah sebesar 33,7\%, Butiran pecah 100/98,82, Nilai CBR adalah sebesar 62,28\%, nilai d maks adalah sebesar $2,187 \mathrm{gr} / \mathrm{cm}^{3}$ dan Wopt adalah sebesar 5,37 \%.

2. Gradasi agregat yang berasal dari material quarry Desa Muara Takus memenuhi persyaratan Spesifikasi 2010 revisi 3. 


\section{DAFTAR PUSTAKA}

Achmad F., 2017, Pemanfaatan Materila Lokal Quarry Longalo Sebagai Bahan Lapisan Pondasi Bahan Lapisan Pondasi Atas Jalan Raya, Seminar Nasional Sains dan Teknologi 2017, Fakultas Teknik Sipil Universitas Muhammadiyah, Jakarta.

Anonim, 1989, Tata Cara Pelaksanaan

Lapis Aspal Beton (Laston) Untuk Jalan Raya, SNI 03-17371989, Direktorat Jenderal Bina Marga, Departemen PU, Jakarta.

Anonim, 1990, Standard Specification for Transportation Materials and Methods of Sampling and Testing, 15th ed, AASHTO, Washington, DC.

Badan Standar Nasional Indonesia, Cara Uji Berat Jenis dan Penyerapan Air Agregat Kasar SNI 1969-2008.

Badan Standar Nasional Indonesia, Cara Uji Berat Jenis dan Penyerapan Air Agregat Halus SNI 1970-2008.

Badan Standar Nasional Indonesia, Cara Pengujian Keausan Agregat dengan mesin abrasi Los Anggeles SNI 2417:2008.

Badan Standar Nasional Indonesia, Metode pengujian Analisa Saringan Aggregat Halus dan Kasar SNI 03-1968-1990.
Dinas Pekerjaan Umum, 2010, Spesifikasi Umum Binamarga 2010 Revisi 3, Dinas Pekerjaan Umum Bidang Binamarga, Jakarta.

Rizal F., Saleh SM., Yunus Y., 2014, Karakteristik Campuran Laston $A C-B C$ dengan Menggunakan Agregat Kasar yang Berbeda Nilai Abrasi, Jurnal Teknik Sipil Pascasarjana Universitas Syiah Kuala, Volume 3, Nomor 3 : 7988.

Sukirman S., 1999, Perkerasan Lentur Jalan Raya, Nova, Bandung.

Sukirman S., 2005, Campuran Beraspal Panas, Granit, Bandung. Suherry, Saleh SM., Yunus Y., 2014, Kajian Campuran Agregat Kasar Yang Berbeda Abrasi Terhadap Parameter Marshall menggunakaceh Utara) $\quad 60 / 70$ Untuk Laston AC-WC (Studi Kasus: Agregat Kab. Gayo, Jurnal Teknik Sipil, Pascasarjana, Universitas Syiah Kuala, Volume 3, Nomor 2 : 130-138.

Toruan A., 2013, Pengaruh Porositas Agregat Terhadap Berat Jenis Maksimum Campuran, Jurnal Sipil Statik, Volume 1, Nomor 3, Fakultas Teknik Sipil, Universitas Samratulangi. 